\title{
Optical-televiewer-based identification and characterization of material facies associated with an Antarctic ice-shelf rift
}

\author{
Bryn HUBBARD, ${ }^{1}$ Jean-Louis TISON, ${ }^{2}$ Frank PATTYN, ${ }^{2}$ Marie DIERCKX, ${ }^{2}$ \\ Thierry BOEREBOOM, ${ }^{2}$ Denis SAMYN ${ }^{2,3}$ \\ ${ }^{1}$ Centre for Glaciology, Institute of Geography and Earth Sciences, Aberystwyth University, Aberystwyth, UK \\ E-mail: byh@aber.ac.uk \\ ${ }^{2}$ Département des Sciences de la Terre et de l'Environnement, Faculté des Sciences, Université Libre de Bruxelles, \\ Bruxelles, Belgium \\ ${ }^{3}$ Department of Mechanical Engineering, Nagaoka University of Technology, Nagaoka, Japan
}

\begin{abstract}
We have drilled 13 boreholes within and around a through-cutting rift on the (unofficially named) Roi Baudouin Ice Shelf, East Antarctica. Logging by optical televiewer (OPTV) combined with core inspection has resulted in the identification and characterization of several material facies. Outside the rift, OPTV-imaged annual layering indicates $\sim 150$ years of accumulation over the $66 \mathrm{~m}$ length of one of the boreholes. Luminosity analysis of this image also reveals the presence of numerous dark melt layers as well as a systematic decrease in background luminosity, interpreted in terms of a progressive increase in light transmission during firnification. We identify four material facies within the rift: snow, granular ice, marine ice and unconsolidated platelets. We interpret the granular ice facies as snow that has been saturated by percolating sea water, and the underlying marine ice as compacted buoyant platelets that have adhered to the rift base. Core sections reveal the presence of tubular channels within the marine ice, indicating that it is macroporous and permeable to sea water. The lower boundary of this facies merges into a mushy layer of unconsolidated platelets that were successfully imaged by OPTV, revealing irregular sub-horizontal layering similar to that reported previously on the basis of (directional) borehole video.
\end{abstract}

\section{INTRODUCTION}

An increasing body of evidence indicates that ice shelves are not composed exclusively of relatively uniform meteoric snow, firn and ice. Instead, they appear to be characterized by an intricate network of inherited structural weaknesses (e.g. Shabtaie and Bentley, 1982; Glasser and Scambos, 2008) and to be composed of several different material types or facies, including marine ice formed by the aggregation and compaction of buoyant platelets formed within the sub-iceshelf water cavity (e.g. Morgan, 1972; Engelhardt and Determann, 1987; Oerter and others, 1992; Tison and others, 1993; Eicken and others, 1994; Fricker and others, 2001; Holland and others, 2009). Indeed, this spatial variability in material composition (and therefore response to imposed stresses) may be central to dictating rates and patterns of both normal ice-shelf flow and ice-shelf disintegration during break-up. For example, the break-up pattern of the Larsen B ice shelf, Antarctic Peninsula, could only be modelled successfully upon introducing widespread spatial variations in ice softness, in this case assumed to involve marine or suture ice (Khazendar and others, 2007). Steady-state modelling of the Larsen $\mathrm{C}$ ice shelf also shows an improved match between modelled and measured surface velocity vectors once spatial variations in ice softness, principally linear filaments of suture ice, are incorporated into the model (personal communication from D. Jansen, 2011). It is therefore clearly important to our understanding of current and future ice-shelf behaviour that we have a good knowledge of the spatial composition of ice shelves and in particular of zones of basal melting and of marine ice accretion.

One major recent development in terms of identifying and quantifying sub-ice-shelf processes and materials involves exploration by autonomous vehicles (Jenkins and others, 2010). However, such expeditions are still in their infancy and are logistically demanding, restricting spatial coverage. Further, despite accessing the underside of ice shelves, they do not yet sample ice directly. Options for accessing and sampling from the interior of ice shelves directly therefore rely primarily on borehole drilling from the surface. For example, the Amery Ice Shelf Ocean Research (AMISOR) project (Craven and others, 2004, 2005, 2009; Roberts and others, 2007; Treverrow and others, 2010) drilled to the base of the Amery Ice Shelf, East Antarctica, at two locations along a flowband underlain by marine ice. These borehole logs reveal that continental ice is underlain by a $\leq \sim 200 \mathrm{~m}$ thick layer of marine ice formed by the adhesion of buoyant platelets onto the ice-shelf base. This marine ice layer is also known, from the analysis of core segments and borehole video (Craven and others, 2005), to become progressively more permeable and less consolidated towards its base. Specifically, the video analysis revealed several material properties of both the continental ice and the underlying marine ice, including the presence of frequent (relatively dark) melt layers and lenses within the bubbly (and therefore brighter) continental ice, and the presence of platelet-like crystals both forming the underlying marine ice and suspended within the borehole fluid. Video footage also revealed that the marine ice hosted brine cells and had a layered structure, both of which increased in intensity towards the ice-shelf base until eventually, within some tens of metres of the shelf-water interface, the texture of the ice became flaky and the brine cells opened up to form voids, resulting in highly permeable 'honeycomb' ice (Craven and others, 2005). 


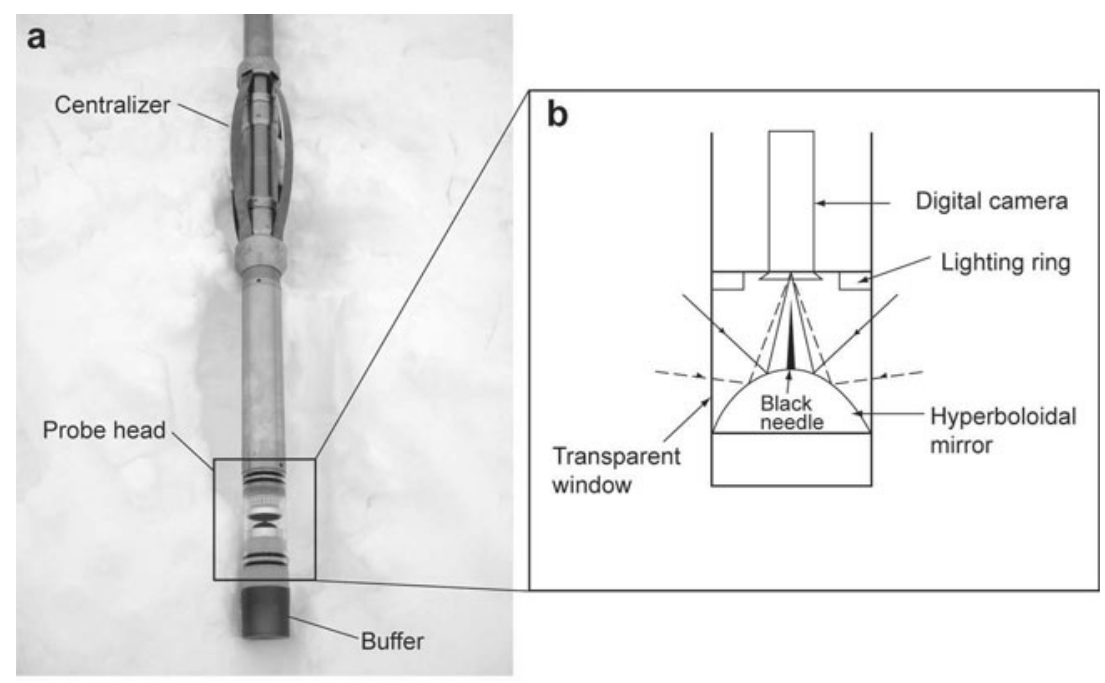

c

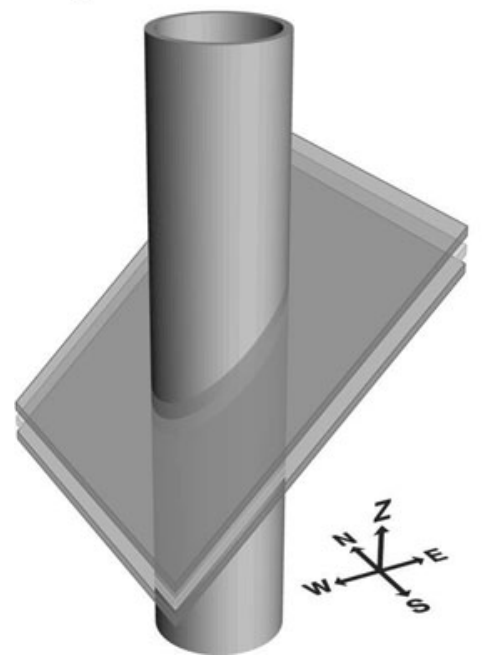

d

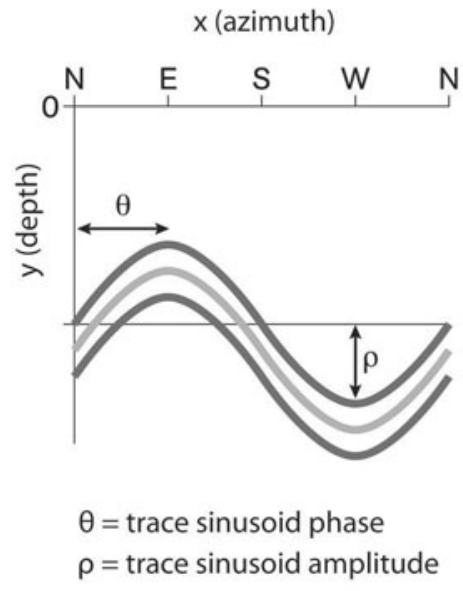

Fig. 1. Illustration of the principles of OPTV operation. (a) Image of OPTV probe and (b) expanded sketch of probe head, (c) schematic illustration of a borehole intersecting three closely spaced layers dipping west and (d) illustration of their equivalent sinusoids on the raw OPTV image.

Drilling through ice shelves is logistically demanding and slow, particularly since most such shelves are several hundred metres thick even at their seaward edge. One means of reducing this demand may be to drill boreholes through the relatively thin base of ice-shelf rifts. Such rifts are common, particularly in zones of high lateral shear near the margins of ice-shelf flow units (Glasser and others, 2009), and the infilling melange may only be some metres to tens of metres thick (e.g. Fricker and others, 2005). Although this melange is largely composed of wind-blown snow, frozen sea water and fragments of ice talus, distinguishing it from the internal composition of the ice shelf proper, Khazendar and others (2001) and Khazendar and Jenkins (2003) demonstrated that rifts are also highly likely to be sites for the rapid formation of marine ice from below. Thus, drilling through the base of a through-cutting rift may well also provide ready access to newly formed and actively forming marine ice, as well as to other melange materials.

Once boreholes have been drilled through an ice shelf, logging by digital optical televiewer (OPTV) has the potential to provide important information in terms of identifying and characterizing the ice types intersected. OPTV differs in one fundamental respect from traditional (directional) borehole video in that OPTV acquires a geometrically accurate image of the complete borehole wall. This is achieved by the probe's downward-looking digital camera recording a $360^{\circ}$ annular image of the borehole wall as reflected in a hyperboloidal mirror (Fig. 1a and b). Accurate winch control then allows the probe to be raised and lowered at a precise rate along the borehole, typically producing images with a vertical resolution that can be user-set to a pixel dimension as small as $1 \mathrm{~mm}$ and at a lateral resolution of either 360 or 720 pixels per row $(\sim 1.0 \mathrm{~mm}$ and $\sim 0.5 \mathrm{~mm}$ per pixel, respectively, for a borehole of $12 \mathrm{~cm}$ diameter). This geometrical accuracy provides a powerful means of mapping the structures that intersect a borehole wall because each visible intersecting plane appears as a sinusoidal trace on the raw OPTV image. Here, the dip and dip-direction of each such plane (orientated by magnetometers located within the OPTV probe) are represented respectively by the amplitude and phase of the associated sinusoid (Fig. 1c and d). Structural analysis of an OPTV log thereby allows all such features to be located, characterized in terms of their thickness and appearance, and their orientations to be logged. 
OPTV was recently applied for the first time to ice boreholes by Hubbard and others (2008). Subsequently, Roberson and Hubbard (2010) applied the technique to an array of boreholes drilled by hot water at Midre Lovénbreen, Svalbard, in an attempt to determine the structural composition of this polythermal valley glacier. Here, OPTV logs successfully revealed bubble-rich layers and bubble clouds, debris bands (including individual clasts) and several generations of stratification and folding. In this case, where boreholes were drilled by hot water and no core was therefore retrieved, the OPTV analysis was particularly valuable in that it allowed 'virtual' core images to be recreated by rolling the raw (outward-looking) images acquired of the borehole walls and viewing them inwards. OPTV analysis can also potentially provide important complementary information from boreholes from which actual ice core has been recovered. First, OPTV views laterally into the ice surrounding the borehole, thereby providing a deep-field image with the capacity to reveal properties not easily identifiable from (or intersected by) a core that is typically $8-12 \mathrm{~cm}$ in diameter. Second, OPTV images cover the entire length (and circumference) of a borehole wall, whereas core may not be retrieved from the borehole's full length, for example being absent from englacial channels or voids. Core sections can also be fractured beyond reconstruction. Third, OPTV imaging can view unconsolidated materials that may not be recoverable as a solid core. This facility may be particularly valuable, for example in boreholes that intersect unconsolidated honeycomb ice or sub-ice-shelf platelets. Despite this potential, however, OPTV has not yet been applied to iceshelf boreholes.

In this paper, we report on the character and genetic interpretation of material facies as revealed by OPTV logs and preliminary core inspection from a series of boreholes drilled in and around a through-cutting rift located near the seaward edge of the Roi Baudouin Ice Shelf (RBIS), Antarctica. The aims of the study are twofold: (1) to evaluate the suitability of OPTV logs for the investigation of ice-shelf facies; and (2) to report on the spatial prevalence of, and to provide preliminary interpretations for, the facies intersected by our boreholes on the RBIS.

\section{FIELD SITE AND METHODS}

\section{Field site}

The (unofficially named) RBIS is located on the Princess Ragnhild Coast, East Antarctica, at $\sim 70^{\circ} \mathrm{S}, 24^{\circ} \mathrm{E}$ (Fig. 2a). The ice shelf extends southwest-northeast for $\sim 350 \mathrm{~km}$ along the coast and has a flow-parallel width of $\sim 50$ $100 \mathrm{~km}$. The rift investigated herein is located within $\sim 5 \mathrm{~km}$ of the seaward edge of the ice shelf and both are aligned approximately parallel to each other (Fig. 2b). The rift forms the easternmost limb of a suite of fractures related to the presence of an ice rise located $\sim 10 \mathrm{~km}$ upflow. Measured ice velocity in the region of the rift is $\sim 350-380 \mathrm{~m} \mathrm{a}^{-1}$ (Pattyn and others, 2005), markedly lower than that predicted theoretically in the absence of the ice rise. The ice shelf overlies a relatively shallow ocean cavity with a sub-ice-shelf water column thickness of 200-300 m (Pattyn and others, unpublished information). We drilled 13 boreholes, each 5-66 m long, in either the rift or the adjacent ice shelf. Of these, six penetrated the base of the rift, extending

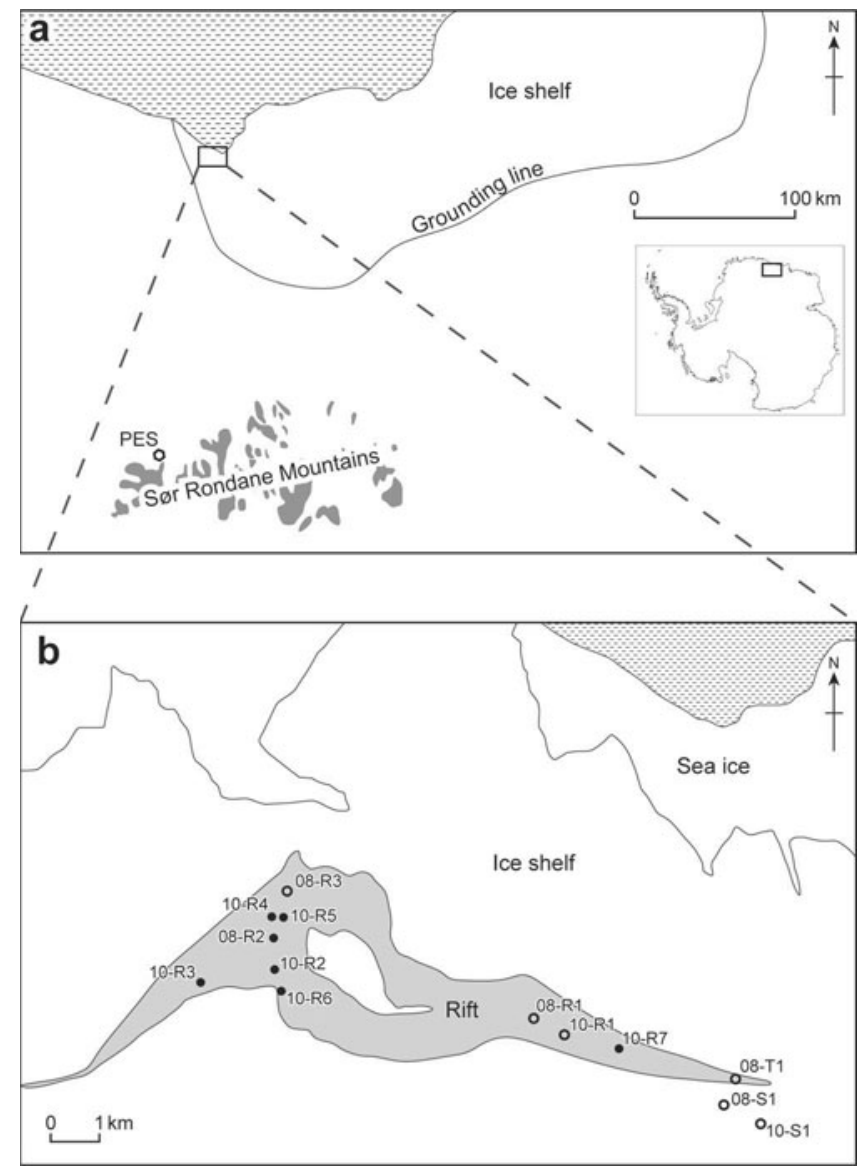

Fig. 2. Location map of (a) the general study site on the Roi Baudouin Ice Shelf (PES is Princess Elisabeth Station) and (b) the individual boreholes reported herein. Boreholes logged by OPTV are represented as open circles.

into the underlying cavity, and six were logged by OPTV (Fig. 2b; Table 1).

\section{Methods}

Boreholes were drilled (during December 2008 or December 2010) either by a mechanical SIPRE-type corer or by an adapted Eclipse ice drill. The latter was modified to enable coring through permeable ice saturated with sea water, requiring contacts within the drill assembly (including those within the slip ring) to be electrically isolated. Importantly, these adaptations allow the Eclipse drill to operate in boreholes filled with sea water, permitting coring below the local water level to the base of the ice shelf. Once drilled, OPTV analysis was carried out as soon as possible and usually within some tens of minutes in order to avoid borehole closure by freezing and, where boreholes penetrated the cavity, clogging by buoyant platelets rising up the sea-water column in the boreholes. The latter effect was unfortunately common, generally occurring within some minutes of the corer being removed from the hole and effectively preventing OPTV logging of several rift boreholes. Once logged, OPTV images were collated, analysed and prepared for presentation (including rolling to create virtual core images) using WellCAD software. This analysis included calculating the luminosity (expressed in nondimensioned units of RGB pixel brightness) of each $1 \mathrm{~mm}$ depth step, represented by the mean value of each ring of 720 pixels. Within some metres (depending on the optical 
Table 1. Summary data for boreholes cored on the RBIS in 2008 and 2010

\begin{tabular}{|c|c|c|c|c|c|c|}
\hline Borehole & Location & Northing* & Easting* & $\begin{array}{c}\text { Length } \\
\mathrm{m}\end{array}$ & OPTV & Note \\
\hline 08-S1 & Shelf & 702140.7 & 242711.3 & 15.24 & Yes & Terminated englacially in water-saturated firn \\
\hline 08-T1 & Rift tip & 702125.0 & 242733.0 & 38.28 & Yes & Terminated englacially in firn \\
\hline 08-R1 & Rift & 702114.5 & 242537.6 & 9.65 & Yes & Terminated englacially in water-saturated ice \\
\hline $08-\mathrm{R} 2$ & Rift & 702012.5 & 241309.2 & 18.40 & No & Penetrated rift base into platelet ice/cavity \\
\hline 08-R3 & Rift & 701928.6 & 241322.4 & 13.26 & Yes & Penetrated rift base into platelet ice/cavity \\
\hline $10-S 1$ & Shelf & 702138.9 & 242714.9 & 66.40 & Yes & Terminated englacially in ice-shelf ice \\
\hline $10-\mathrm{R} 1$ & Rift & 702044.4 & 242107.8 & 13.56 & Yes & Penetrated rift base into platelet ice/cavity \\
\hline $10-R 2$ & Rift & 702005.6 & 241206.2 & 7.29 & No & Penetrated rift base into platelet ice/cavity \\
\hline $10-\mathrm{R} 3$ & Rift & 702013.8 & 240948.1 & 29.71 & No & Penetrated rift base into platelet ice/cavity \\
\hline $10-\mathrm{R} 4$ & Rift & 701932.3 & 241200.0 & 19.19 & No & Terminated englacially in water-saturated rift ice \\
\hline $10-\mathrm{R} 5$ & Rift & 701932.3 & 241221.3 & 21.44 & No & Terminated englacially in water-saturated rift ice \\
\hline $10-R 6$ & Rift & 702020.1 & 241211.9 & 4.86 & No & Penetrated rift base into platelet ice/cavity \\
\hline $10-R 7$ & Rift & 702053.2 & 242249.4 & 11.02 & No & Terminated englacially in water-saturated rift ice \\
\hline
\end{tabular}

*These locations were recorded at the time of coring. They have since been advected with the motion of the ice shelf, which in this area is moving in an approximately northerly direction by $\sim 350-380 \mathrm{~m} \mathrm{a}^{-1}$ (Pattyn and others, 2005).

transmissivity of the material being cored) of the borehole surface, recorded light is dominated by that transmitted from the surface, but below this zone it is exclusively composed of that reflected back from the borehole walls to the OPTV sensor. Since borehole illumination, achieved by a circular array of white LEDs, is uniform in time and therefore also in space as the probe moves along a borehole, the net luminosity of the recorded signal varies with the reflectivity of the material forming the borehole wall.

\section{RESULTS}

\section{Ice-shelf boreholes}

The OPTV logs of the two boreholes cored into the ice shelf proper, 08-S1 and 10-S1 (Fig. 2b; Table 1), reveal similar material properties, with $66 \mathrm{~m}$ long 10-S1 providing the longer record. The log of 10-S1 (Figs 3 and 4), has three notable features. First, regularly repeated dark layers, which have a typical luminosity of $\leq 100$ units lower than the local image background, can be observed along most of the length of the core. The spacing of these layers gradually decreases from $\sim 1.0 \mathrm{~m}$ near the borehole's upper surface (e.g. five regularly spaced darker layers between 4 and $9 \mathrm{~m}$ depth in Fig. 3) to $\sim 0.15 \mathrm{~m}$ near its base (e.g. seven regularly spaced darker layers between 51.5 and $52.5 \mathrm{~m}$ depth in Figs 3 and $4 b)$. Although still visible, these layers are more difficult to distinguish from the (now darker) background towards the base of the borehole. Second, sharply defined very dark layers, typically with a luminosity that is $>100$ units lower than the local image background, are observed intermittently along the full length of the borehole. For example, four distinctive dark bands are located between 30 and $31 \mathrm{~m}$ depth, each of which is $5-20 \mathrm{~cm}$ thick (Figs 3 and 4a). Thus, the luminosity of these layers is typically similar to, or darker than, that of the thinner and more regular layers noted above. Finally, if both the above sets of dark layers are removed from the analysis, the background reflected light intensity of the OPTV log of 10-S1 decreases consistently down the borehole, from typical values of $\sim 400$ near the ice-shelf surface to $\sim 150$ at the base of the borehole, visible in both Figures 3 and 4.

\section{Rift boreholes}

We drilled ten boreholes into the base of the rift proper and one was drilled into the ramp formed in the rift tip (Fig. 2b; Table 1). Several of these boreholes intersected apparently fundamentally different material facies. The OPTV log of 08$\mathrm{T} 1$, cored for $38 \mathrm{~m}$ into the rift tip, was of uniformly high luminosity, similar to the material forming the matrix between the dark layers in 10-S1 (above). Indeed, the OPTV $\log$ of 08-T1 contrasts with that of 10-S1 in that the former is characterized by (1) fewer dark layers and (2) no apparent systematic decrease in the intensity of the background reflected light with depth.

All of the remaining ten boreholes were drilled directly into the base of the rift (Fig. 2b), intersecting a series of material facies which always appeared in the same order but which were not all present at every borehole. These facies are as described below.

\section{Surface snow}

Snow was present in the uppermost sections of most rift boreholes and was identified visually at the surface and as a very bright backscatter in OPTV logs. Where present, this layer extended only for a few metres below the surface.

\section{Granular ice}

This facies, defined by a distinctively granular structure, was relatively massive and appeared highly uniform on OPTV logs. However, it did occasionally contain isolated bubble clusters, particularly at depth. It was present in most rift boreholes, but generally decreased in representation westwards, away from the rift tip. The upper surface of the granular ice also commonly coincided with the level of the saline-water table (sea level) within the rift and the two were always observed to be in close proximity. This facies typically extended for some metres below sea level.

\section{Marine ice}

Progressing down-borehole, granular ice gradually gave way to a less massive and more strongly layered ice facies that was very similar in character to the marine ice imaged on the Amery Ice Shelf (Craven and others, 2005, 2009). This facies was present in all rift boreholes, either on its own or 

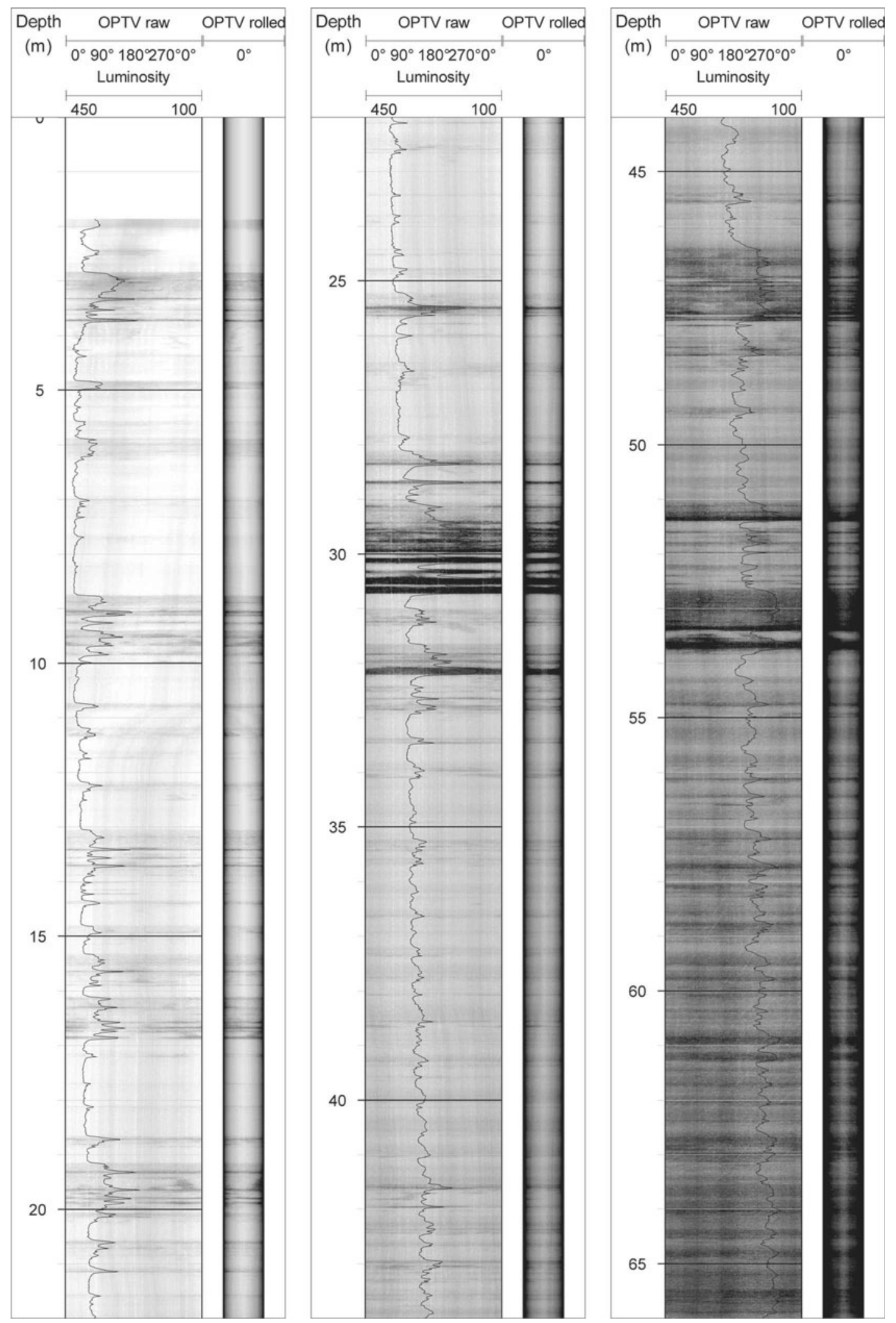

Fig. 3. OPTV log of the full length of ice-shelf core 10-S1. The raw OPTV image is plotted on the left-hand side of each panel and its rolled equivalent is plotted on the right. The luminosity trace overlaid on the raw OPTV image is sampled each millimetre in the vertical and is scaled to decrease, over the range 450-100 (non-dimensioned) units, to the right.

beneath the granular facies (and never above it), and showed an increased prevalence further west, away from the rift tip, as the thickness of the granular ice diminished. Indeed, in some of the most westerly boreholes (e.g. 08-R3), the marine ice facies extended the full thickness of the rift, cropping out at its upper surface (Fig. 5). Although this facies appeared to be homogeneous in OPTV images, containing no notable bubble-defined layering, it was characterized by a green hue, particularly under transmitted light near the surface. We interpreted this as due to the presence of a low 


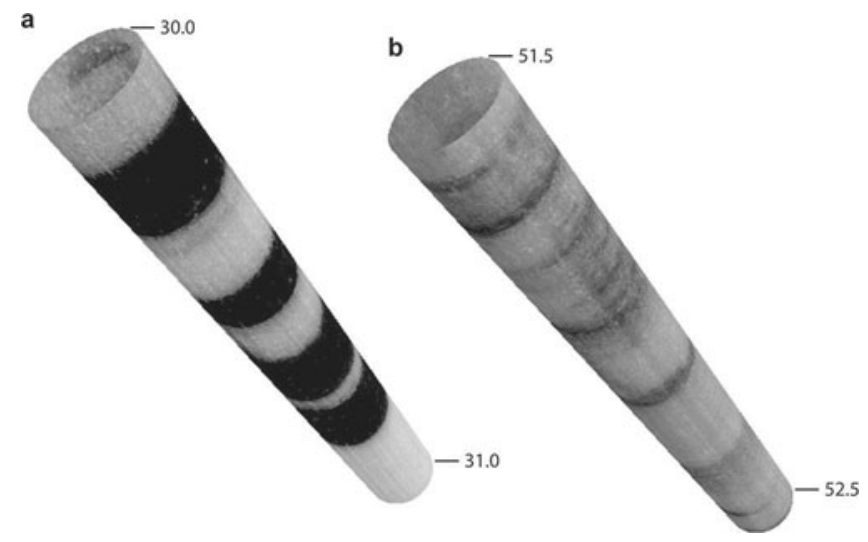

Fig. 4. Expanded rolled OPTV images of two $1 \mathrm{~m}$ long virtual core segments from ice-shelf core 10-S1 (Fig. 3): (a) 30-31 m depth and (b) $51.5-52.5 \mathrm{~m}$ depth.

concentration of chlorophyll-bearing marine algae, supported by occasional observations of dense patches of algae in core sections recovered from this facies. Such algae were not observed within the overlying granular ice. Although not clearly imaged by OPTV, core sections of marine ice did reveal the development of a strong sub-horizontal crystal alignment with depth, giving the facies a fissile texture.

One further notable aspect of this facies is that it contained sinuous tubular channels, similar in appearance to large worm-holes (Fig. 6). These tubes were intersected by our cores on several occasions (e.g. 10-R3) and are typically $1-3 \mathrm{~cm}$ in diameter and appear to have no preferential orientation. Unfortunately, no OPTV log was recovered from a borehole segment intersecting such a tube, principally because most of the rift holes became blocked with buoyant ice platelets before OPTV logging was possible. However, the tubes were observed directly in the recovered core sections (Fig. 6).

\section{Ice platelets}

Towards the base of the rift cores, the marine ice became so fragile that it formed only a weakly consolidated mass of thin platy crystals (Fig. 7). Below this point, the crystals were effectively unconsolidated and samples could no longer be retrieved by traditional coring (since the retaining core dogs could no longer hold the unconsolidated slurry within the barrel), effectively forming a sea-water-saturated 'mushy layer' (Feltham and others, 2006). This transition marked the indistinct interface between the base of the solid ice shelf and the platelet-rich uppermost layers of the underlying sea water. One OPTV log, recovered from 08-R3 (Figs 5 and 8), did extend for $\sim 4 \mathrm{~m}$ below the point at which solid core was no longer retrievable, thereby presumably penetrating the uppermost layers of the platelet-rich cavity. This lowermost section of the OPTV log of 08-R3 revealed the presence of unconsolidated material that was characterized by smallscale sub-horizontal wavy layering (Fig. 8), strikingly similar in appearance to that imaged by directional video at the base of the Amery Ice Shelf (fig. 13 in Craven and others, 2005). These layers were repeated every few centimetres throughout the facies. Unfortunately, OPTV images could not be obtained from deeper into this facies because the buoyancy of the unconsolidated mass prevented further OPTV probe penetration.

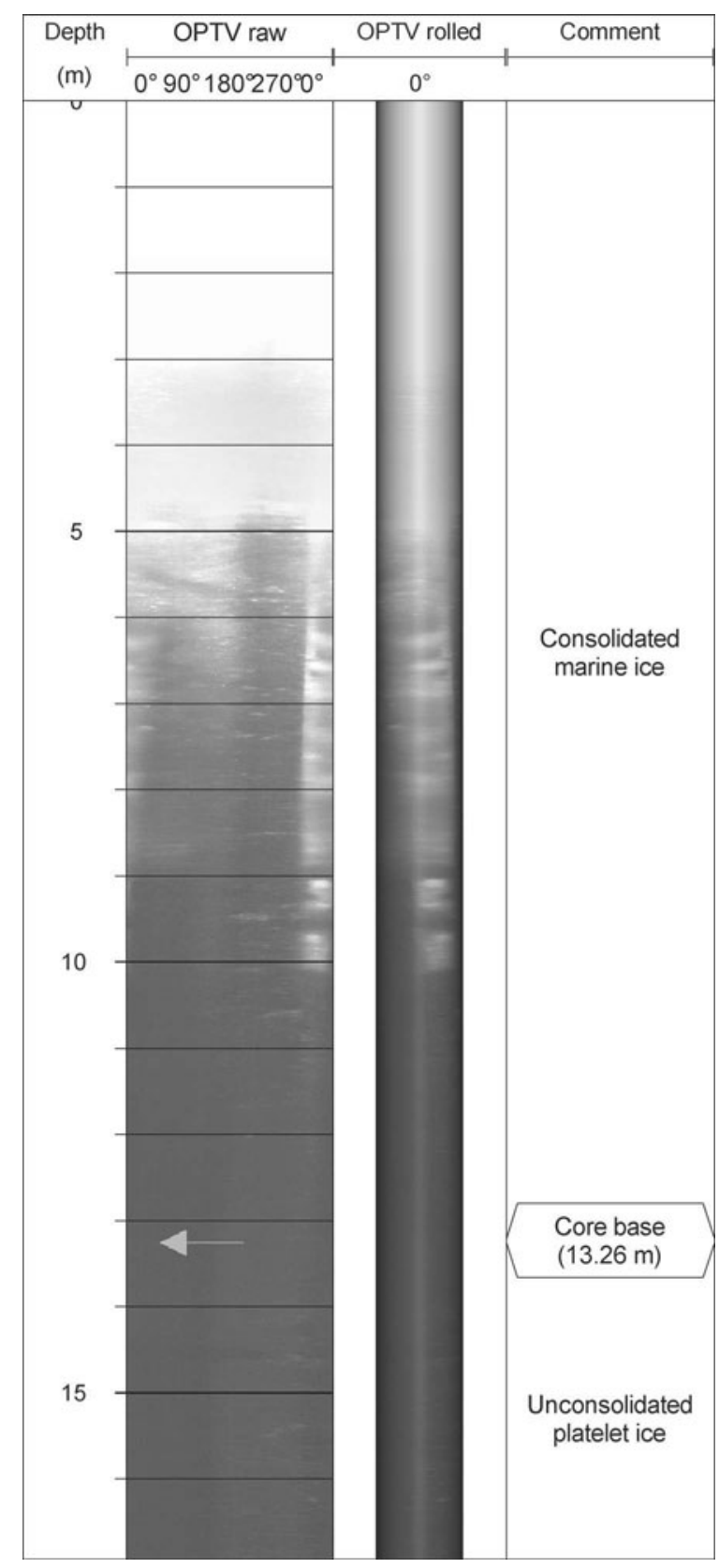

Fig. 5. OPTV log of the full length of rift core 08-R3 with (progressing left to right) the raw OPTV image, the rolled OPTV image and annotations. Note that no solid core was retrieved from below $13.26 \mathrm{~m}$ depth where unconsolidated platelet ice was encountered. Although not visible in the OPTV log, the 'core base' at $13.26 \mathrm{~m}$ marks the point at which no more core could be recovered by mechanical coring. An annotated expansion (represented in three dimensions as a virtual core) of the unconsolidated platelet ice forming the lowermost part of this log is presented in Figure 8.

\section{INTERPRETATION}

\section{Ice-shelf boreholes}

The ice-shelf cores (08-S1 and 10-S1) both began in surface snow. However, while the former terminated in firn, the latter (being $>66 \mathrm{~m}$ long) penetrated through the firn and into the underlying ice. Three specific characteristics of the OPTV images retrieved from 10-S1 were reported: (1) regular layering by dark bands, (2) intermittent layering by thicker dark bands and (3) a general down-core decrease in 


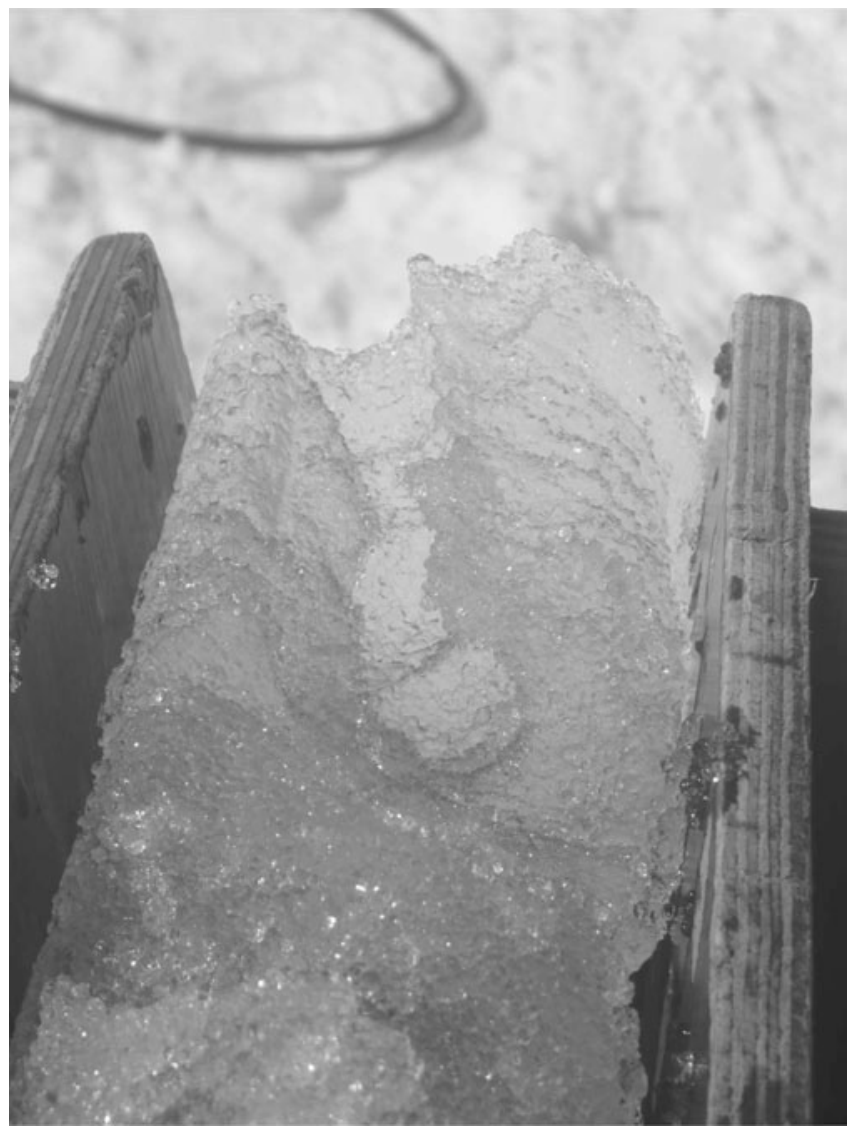

Fig. 6. Photographic image of a typical worm-hole-like tubular conduit located within core 10-R3. The core is retained within a wooden core holder and the tube extends approximately vertically along the top of the core. The tube is $\sim 25 \mathrm{~mm}$ in diameter.

luminosity. We interpret the first of these, the 'primary' layering, as annual layers similar to those previously identified on the basis of directional video by for example Hawley and others (2003) and Hawley and Morris (2006). In such logs, the darker zones mark the more melt-influenced icy layers formed during the summer, and the lighter zones the colder winter accumulation. The summer layer spacing of $\sim 1.0 \mathrm{~m}$ near the surface of 10-S1 accords with regional mass-balance approximations which indicate an accumulation of $\sim 0.3 \mathrm{~m}$ w.e. $\mathrm{a}^{-1}$ (Van de Berg and others, 2006). However, this primary layering was frequently disrupted by the second layer type, which was darker (indicating less reflected light, consistent with bubble-poor ice) and had sharper boundaries with the matrix material. These characteristics, along with the intermittent occurrence of this 'secondary' layering along the borehole, are consistent with an interpretation as refrozen surface melt layers. Although comparison with the spacing of annual layers (below) suggests that these melt events do not occur each summer, they do appear throughout the full borehole length. The presence of these secondary melt layers also makes it difficult to derive an age-depth relationship for 10-S1 by primary-layer counting. However, the age range of this borehole may be approximated by interpolating primarylayer spacing from zones that are devoid of melt layers (e.g. $5-9,17-19,22-25,36-40,50-51$ and 56-60 m in Fig. 3), suggesting that the record extends back for $\sim 150$ years from present. Although the frequent melt layers disrupt the core's potential to provide an undisturbed palaeoenvironmental

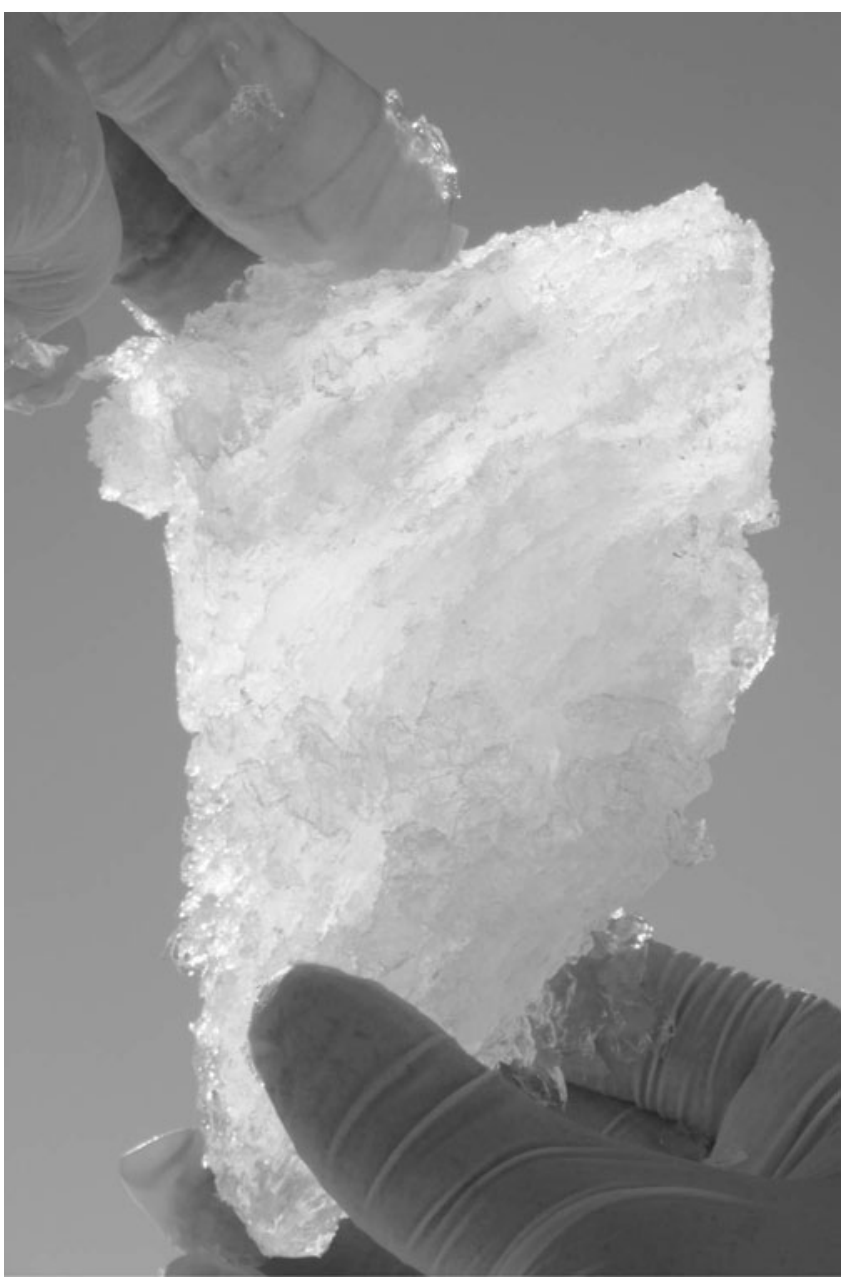

Fig. 7. Photographic image of a sample of highly flaky marine ice just above the point at which it becomes completely unconsolidated and can no longer be retrieved by coring.

record, they do provide independent information on the scale and timing of major surface melting events and directly affect only a minor proportion of the core's total length. Palaeoenvironmental reconstructions should therefore still

a

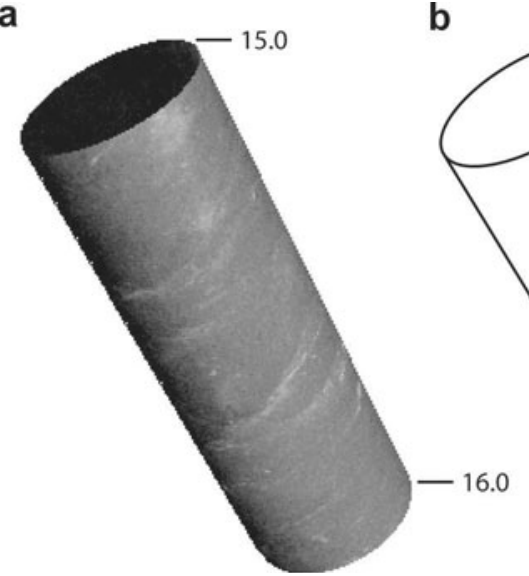

b

Fig. 8. Rolled OPTV virtual core image of a $1 \mathrm{~m}$ interval (15-16 m) near the base of core 08-R3 (Fig. 5): (a) actual OPTV image, (b) interpretative sketch. Brighter light reflected off repeated irregular sub-horizontal layering is interpreted as marking the boundary of layers of aggregated sub-ice-shelf platelets. 
be possible from cores such as this, as long as the physical influence of melting events is isolated and removed from the analysis. Finally, we interpret the general down-hole decrease in the luminosity of the OPTV image of 10-S1 (at a rate of 3.5 units $\mathrm{m}^{-1}$ depth, averaged linearly over the full $66 \mathrm{~m}$ borehole length; Fig. 3) in terms of progressive firnification, specifically the gradual isolation and coalescence of bubbles resulting in a net increase in the optical transmissivity (and concomitant decrease in reflectivity) of the borehole wall.

\section{Rift boreholes}

The material imaged in the rift tip (08-T1) was similar to that forming the matrix of 10-S1. However, in contrast to the OPTV $\log$ of 10-S1, that of 08-T1 is uniform and includes only three slightly darker layers that are each only a few centimetres thick. Further, luminosity does not decrease measurably with depth along 08-T1. We interpret these properties, in association with the location of the borehole in the rift tip, as indicative of infilling by blown snow (as opposed to surface firnification on the ice shelf; see above). This process, described by Leonard and others (2008) for a rift on the Ross Ice Shelf, would result in little or no seasonal signal, while the possible rapidity of aeolian infilling may also explain the absence of firnification-related bubble nucleation with depth.

Within the rift proper, we interpret the uppermost granular ice facies as snow and firn that have become saturated by percolating saline water, causing the observed grain rounding. This interpretation is also consistent with the general thinning of this facies westwards, away from the apex of the rift, where the rate of surface accumulation by snow trapping is expected to be lower. Progressing westwards and with depth into the base of the rift, this facies gives way to the marine ice facies. All of the properties of this facies, and in particular its occasional high algal content and gradual disintegration into unconsolidated platelets at the base of the rift boreholes, suggest formation by the progressive accumulation and compaction of buoyant platelets formed within the sub-ice-shelf cavity, consistent with previous interpretations. The fact that these platelets rose up the water column rapidly in completed boreholes, commonly preventing OPTV access within some minutes of drilling penetrating the cavity $(08-\mathrm{R} 3$ being the sole exception in this study), indicates that the platelets were both buoyant and mobile. The ubiquitous presence of this facies within our rift boreholes, typically to a thickness of some metres to tens of metres, also indicates that platelet marine ice formed throughout the rift.

Finally, the unique observations of worm-hole-like tubes within the granular ice and marine ice facies provide clear evidence of conduit-based water flow through the lowermost layers of the rift melange. We assume that these conduits are formed during the early stages of ice formation when the material is still erodible and then become frozenin as the material consolidates and (possibly) de-waters. It is therefore apparent that this marine ice is highly porous and permeable, consistent with previous indications (e.g. Craven and others, 2005). One characteristic of marine ice that remains poorly understood is its very low measured bulk salinity (typically 0.05-0.5\%; e.g. Tison and others, 2001) relative to that measured in sea ice (typically $1-20 \%$; Weeks, 2010), despite both ice types being formed by the aggregation and consolidation of frazil ice frozen from sea water. Eicken and others (1994) argued that the standard mechanisms of post-formational desalination proposed for sea ice are in fact insufficiently effective to reduce the salinity of marine ice to measured values. Instead, these authors tentatively invoked a mechanism of salt-water expulsion from already low-salinity platelets during buoyancy-driven aggregation and densification. Tabraham (1998) introduced the 'mushy layer' concept into a solidification model for marine ice. In this approach, relatively recently proposed to describe the desalination process in sea ice, convective movements in the interstitial liquid are driven by density instabilities due to salinity gradients in a temperature field increasing downwards. This leads to the development of convective 'chimneys' known as 'brine channels' in sea ice, exporting salts from the mushy layer to the ocean below. However, Tabraham (1998) also recognized that, although the model of drainage through channels produced some desalination in marine ice, the amount of desalination was found to be less than the levels observed within actual marine ice, the main problem being shutdown of the flow with continuing solidification. The author suggested that combining mushy-layer desalination with compaction might be sufficiently efficient to reach the observed low salinity values. Alternatively, Tison and others (2001) showed that by treating marine ice as a two-phase compound (pure frazil ice crystals in a consolidating interstitial fluid) and applying a boundary-layer model for consolidation of the interstitial liquid, marine ice salinities could be reproduced if fractionation coefficients derived from the solidification of freshwater ice were used rather than those for columnar (dendritic skeletal layer) sea-water ice.

The $0.05-0.5 \%$ salinity range discussed above has generally been observed in thick $\left(10^{2}-10^{3} \mathrm{~m}\right)$ marine ice layers, and to the best of our knowledge no internal desalination chimneys (either active or relict) have been described in such layers. The marine ice salinity range in our RBIS dataset covers a range more typical of sea ice $(\leq 9 \%$ in the lower layers), with very low salinities $(0.1 \%$ ) only being measured in the upper few metres over a total thickness of a maximum of 10-20m (Pattyn and others, unpublished information). The occurrence of the wormhole-like tubes in the less consolidated lower layers could therefore represent the signature of mushy-layer-like convection processes in the early stages of consolidation of the marine ice layer. The fact that these tubes lack the typical vertical tree-like structure of sea-ice brine channels might reflect the geometrical control of the sub-horizontal accumulation pattern of the loose large frazil ice platelets. An alternative, or supplementary, hypothesis is that once the marine ice layer is formed, salt would continue to be expelled from the layer by freezing-front rejection accompanying ongoing recrystallization within the layer. The removal of that salt-rich water through an effective internal drainage system would then decrease the bulk salinity of the remaining marine ice. Such a process would also involve the delivery of relatively high-salinity water to the underlying water column.

\section{SUMMARY AND DISCUSSION}

OPTV logging of 13 boreholes, supplemented by visual analysis of their associated cores, from within and around a rift on the seaward edge of the RBIS has revealed the presence and stratigraphy of several distinctive material 
facies. OPTV has the capacity to image these material types along with their internal variability, such as that associated with annual layering in snow, firn and ice. The technique may also have the capacity to provide a rapid boreholebased approximation of firn/ice reflectivity and therefore, indirectly, density. Importantly, the technique also has the capacity to image the immediate sub-ice-shelf cavity which may otherwise be extremely difficult to investigate.

Beyond technique evaluation, this study has resulted in the following glaciological findings and associated implications:

1. That annual layering is present at least in the uppermost layers of the ice shelf (at least for $66 \mathrm{~m}$ ) and that this depth covers a time range of $\sim 150$ years. As anticipated, layer spacing decreases with depth.

2. That surface accumulation has been, for the full length of the record, interrupted by frequent episodes of summer melting. These events have commonly resulted in the formation of ice layers that are several centimetres thick and introduce additional complications in terms of obtaining continuous undisturbed palaeoclimatic records from such cores. Nonetheless, such cores may well be used to provide detailed palaeoclimatic information as long as the firn and ice influenced by the melt layers is excluded from the analysis. OPTV logging can assist in this.

3. That the OPTV logs of ice-shelf snow and firn darken with depth as bubble nucleation causes the reflectance of these materials to decrease. It is therefore possible that borehole-based OPTV luminosity could provide a proxy for the near-surface density of continental snow and ice.

4. That the material filling in the rift tip is blown snow that has been deposited rapidly and which shows very little variation in internal structure.

5. That the melange forming the floor of the rift is composed of distinctive material facies in the following stratigraphic arrangement: surface snow overlies granular ice overlies marine ice overlies unconsolidated platelets. The first two of these facies become less prevalent moving away from the rift tip, such that only marine ice and unconsolidated platelets were present in the westernmost boreholes. We hypothesize that the granular ice forms by the saturation of snow/firn by percolating sea water, while the underlying marine ice forms by the accumulation of buoyant platelets at the base of the solid ice shelf, consistent with previous investigations.

6. That marine ice contains organic matter, presumably of marine origin, giving it a distinctive green hue in OPTV images. Towards its base, marine ice also becomes mushy and is increasingly penetrated by tubular conduits, making the layer highly permeable.

7. That platelet ice is present ubiquitously in thicknesses of at least several metres beneath the rift. These platelets consolidate at the rift base as irregular sub-horizontal layers, but individual crystals appear to be both mobile and buoyant.

These findings and implications are based on OPTV and visual analysis alone and are therefore tentative. Future efforts will focus on direct core sampling in order to evaluate these interpretations by rigorous multi-parameter analysis. Nonetheless it is clear from this research that OPTV-based borehole analysis has a significant contribution to make to the investigation of ice-shelf properties. In particular, the reconstruction of internal layering, which may not always be readily achievable from core analysis, has potential implications for topics such as the interpretation of internal reflecting horizons revealed by ice radar and as a check on core-derived palaeoclimatic reconstructions. Finally, the technique may represent the principal analytical tool in borehole sections from which core segments are missing or broken and in boreholes drilled by steam or hot water from which no ice core may be recovered.

\section{ACKNOWLEDGEMENTS}

This paper forms a contribution to the Belgian Research Programme on the Antarctic (Belgian Federal Science Policy Office), project No. EA/11/3A 'Belgian Ice Sheet Shelf Ice Measurements in Antarctica (BELISSIMA)' and to UK Royal Society grant RG1430. B.H. was also supported by the Climate Change Consortium of Wales (C3W). We thank the International Polar Foundation for Antarctic for support, and A. Hubert, R. Wagemans and K. Soete for invaluable assistance in the field. We also thank two anonymous reviewers and the scientific editor, Helen Fricker, for comments that led to the improvement of the manuscript.

\section{REFERENCES}

Craven M and 6 others (2004) Initial borehole results from the Amery Ice Shelf hot-water drilling project. Ann. Glaciol., 39, 531-539 (doi: 10.3189/172756404781814311)

Craven M and 7 others (2005) Borehole imagery of meteoric and marine ice layers in the Amery Ice Shelf, East Antarctica. J. Glaciol., 51(172), 75-84 (doi: 10.3189/ 172756505781829511)

Craven M, Allison I, Fricker HA and Warner R (2009) Properties of a marine ice layer under the Amery Ice Shelf, East Antarctica. J. Glaciol., 55(192), 717-728 (doi: 10.3189/ 002214309789470941)

Eicken H, Oerter H, Miller H, Graf W and Kipfstuhl J (1994) Textural characteristics and impurity content of meteoric and marine ice in the Ronne Ice Shelf, Antarctica. J. Glaciol., 40(135), 386-398

Engelhardt H and Determann J (1987) Borehole evidence for a thick layer of basal ice in the central Ronne Ice Shelf. Nature, 327(6120), 318-319

Feltham DL, Untersteiner N, Wettlaufer JS and Worster MG (2006) Sea ice is a mushy layer. Geophys. Res. Lett., 33(14), L14501 (doi: 10.1029/2006GL026290)

Fricker HA, Popov S, Allison I and Young N (2001) Distribution of marine ice under the Amery Ice Shelf, East Antarctica. Geophys. Res. Lett., 28(11), 2241-2244 (doi: 10.1029/2000GL012461)

Fricker HA, Bassis JN, Minster B and MacAyeal DR (2005) ICESat's new perspective on ice shelf rifts: the vertical dimension. Geophys. Res. Lett., 32(23), L23S08 (doi: 10.1029/ 2005GL025070)

Glasser NF and Scambos TA (2008) A structural glaciological analysis of the 2002 Larsen B ice-shelf collapse. J. Glaciol., 54(184), 3-16 (doi: 10.3189/002214308784409017)

Glasser N and 7 others (2009) Surface structure and stability of the Larsen C ice shelf, Antarctic Peninsula. J. Glaciol., 55(191), 400-410 (doi: 10.3189/002214309788816597)

Hawley RL and Morris EM (2006) Borehole optical stratigraphy and neutron-scattering density measurements at Summit, Greenland. J. Glaciol., 52(179), 491-496 (doi: 10.3189/ 172756506781828368) 
Hawley RL, Waddington ED, Alley RA and Taylor KC (2003) Annual layers in polar firn detected by borehole optical stratigraphy. Geophys. Res. Lett., 30(15), 1788 (doi: 10.1029/2003GL017675)

Holland PR, Corr HFJ, Vaughan DG, Jenkins A and Skvarca P (2009) Marine ice in Larsen Ice Shelf. Geophys. Res. Lett., 36(11), L11604 (doi: 10.1029/2009GL038162)

Hubbard B, Roberson S, Samyn D and Merton-Lyn D (2008) Digital optical televiewing of ice boreholes. J. Glaciol., 54(188), 823-830 (doi: 10.3189/002214308787779988)

Jenkins A and 6 others (2010) Observations beneath Pine Island Glacier in West Antarctica and implications for its retreat. Nature Geosci., 3(7), 468-472 (doi: 10.1038/ngeo890)

Khazendar A and Jenkins A (2003) A model of marine ice formation within Antarctic ice shelf rifts. J. Geophys. Res., 108(C7), 3235 (doi: 10.1029/2002JC001673)

Khazendar A, Tison JL, Stenni B, Dini M and Bondesan A (2001) Significant marine-ice accumulation in the ablation zone beneath an Antarctic ice shelf. J. Glaciol., 47(158), 359-368 (doi: 10.3189/172756501781832160)

Khazendar A, Rignot E and Larour E (2007) Larsen B Ice Shelf rheology preceding its disintegration inferred by a control method. Geophys. Res. Lett., 34(19), L19503 (doi: 10.1029/ 2007GL030980)

Leonard KC, Tremblay L-B, MacAyeal DR and Jacobs SS (2008) Interactions of wind-transported snow with a rift in the Ross Ice Shelf, Antarctica. Geophys. Res. Lett., 35(5), L05501 (doi: 10.1029/2007GL033005.)

Morgan VI (1972) Oxygen isotope evidence for bottom freezing on the Amery Ice Shelf. Nature, 238(5364), 393-394

Oerter $\mathrm{H}$ and 6 others (1992) Evidence for basal marine ice in the Filchner-Ronne Ice Shelf. Nature, 358(6385), 399-401

Pattyn F, de Brabander S and Huyghe A (2005) Basal and thermal control mechanisms of the Ragnhild Glaciers, East
Antarctica. Ann. Glaciol., 40, 225-231 (doi: 10.3189/ 172756405781813672)

Roberson S and Hubbard B (2010) Application of borehole optical televiewing to investigating the 3-D structure of glaciers: implications for the formation of longitudinal debris ridges, Midre Lovénbreen, Svalbard. J. Glaciol., 56(195), 143-156 (doi: 10.3189/002214310791190802)

Roberts D, Craven M, Cai M-H, Allison I and Nash G (2007) Protists in the marine ice of the Amery Ice Shelf, East Antarctica. Polar Biol., 30(2), 143-153 (doi: 10.1007/s00300-006-0169-7)

Shabtaie S and Bentley CR (1982) Tabular icebergs: implications from geophysical studies of ice shelves. J. Glaciol., 28(100), 413-430

Tabraham J (1998) The desalination of marine ice. (PhD thesis, University of Cambridge)

Tison J-L, Ronveaux D and Lorrain RD (1993) Low salinity frazil ice generation at the base of a small Antarctic ice shelf. Antarct. Sci., 5(3), 309-322

Tison JL, Khazendar A and Roulin E (2001) A two-phase approach to the simulation of the combined isotope/salinity signal of marine ice. J. Geophys. Res., 106(C12), 31387-31 401 (doi: 10.1029/2000JC000207)

Treverrow A, Warner RC, Budd WF and Craven M (2010) Meteoric and marine ice crystal orientation fabrics from the Amery Ice Shelf, East Antarctica. J. Glaciol., 56(199), 877-890 (doi: 10.3189/002214310794457353)

Van de Berg WJ, Van den Broeke MR, Reijmer $\mathrm{CH}$ and Van Meijgaard E (2006) Reassessment of the Antarctic surface mass balance using calibrated output of a regional atmospheric climate model. J. Geophys. Res., 111(D11), D11104 (doi: 10.1029/2005JD006495)

Weeks WF (2010) On sea ice. University of Alaska Press, Fairbanks, AK 